\title{
Constructivist Learning Amid the COVID-19 Pandemic: Investigating Students' Perceptions of Biology Self-Learning Modules
}

\author{
Aaron A. Funa and Frederick T. Talaue \\ De La Salle University, Manila, Philippines \\ https:/ / orcid.org/0000-0002-6648-8825 \\ https://orcid.org/0000-0002-6452-0641
}

\begin{abstract}
Modes of teaching and learning have had to rapidly shift amid the COVID-19 pandemic. As an emergency response, students from Philippine public schools were provided learning modules based on a minimized list of essential learning competencies in Biology. Using a cross-sectional survey method, we investigated students' perceptions of the Biology self-learning modules (BSLM) that were designed in print and digitized formats according to a constructivist learning approach. Senior high school STEM students from grades $11(n=117)$ and $12(n=104)$ participated in a survey using a 3-point Likert-scale questionnaire uploaded online through Google Forms. The survey results indicate that majority of the students perceived the modules positively, suggesting that aspects of the modules that were salient to students corresponded to essential elements of constructivist pedagogies. However, during interviews, students reported several difficulties in learning with BSLM as it was constrained by, to name a few, the use of unfamiliar words, lack of access to supporting resources, slow internet connection, and time constraints. To address these problems, teachers reported that they gave deadline extensions, complemented modules with other channels of support, and used online and offline platforms for reaching out to students to answer their queries and plan out their schedule for the week. The findings across the data sources point to the complex demands of emergency distance education that teachers, as curriculum designers and enactors, need to bear in mind in order to craft productive pedagogies, constructivist or otherwise, during this unprecedented time.
\end{abstract}

Keywords: constructivist learning; COVID-19 pandemic; curriculum materials; scaffolding; student perception; pandemic pedagogy

\section{Introduction}

Our lives during this COVID-19 pandemic have become marked by a persistent sense of uncertainty because of forced lockdowns and necessary quarantines (Caggiano et al., 2020). The education sector has had to make numerous 
emergency adjustments to existing practices (Talidong \& Toquero, 2020; Williamson et al., 2020) in order to continue the provision of educational services. The Department of Education (DepEd) in the Philippines offered two alternative distance learning modalities, namely, pure online and hybrid (online and offline), which were supplemented with contextualized and standardized self-learning modules (SLM) crafted by teachers for each region of the country. In addition, the DepEd generated the Most Essential Learning Competencies (MELC) as a way of decongesting the curriculum and making schooling during the pandemic less stressful (DepEd, 2020a). The MELC-aligned SLM is the backbone of distance learning aimed at making education accessible to students, both online and offline, most especially to those who live in far-flung rural areas without internet access (DepEd, 2020b). The distribution of print and digitized SLM would facilitate distance learning with minimized risks of COVID-19 infection among students and school personnel. However, despite the trainings given to teachers and the quality assurance provided for instructional material and module development, the SLM received negative informal feedback. For example, it was said that the modules required performance of complicated activities, included complex vocabularies that needed to be memorized, and resembled passive lecture formats. With such criticisms, it is easy to imagine the challenges students experienced in understanding target concepts (Çimer, 2012; Gutierrez, 2014; Sañosa, 2013). It now becomes imperative to investigate students' experiences in using the SLM in order to understand their interactions with new curriculum materials and inform similar future curriculum development efforts.

In carrying out the K-12 Basic Education Program, the DepEd is mandated to adhere to sound educational principles including, but not limited to, the utilization of constructivist pedagogical approaches (DepEd, 2019a). Policy standards that were set for new modes of learning delivery during the COVID-19 pandemic stipulated that the content of the SLM use constructivist, inquiry-based, reflective, collaborative, and integrative pedagogical approaches (DepEd, 2019b). In designing the modules, teachers utilized corresponding policy guidelines that defined constructivism as a pedagogical approach that aims to develop learners as active constructors of meaningful knowledge. Such an outcome could be achieved by designing lessons that engage students in internalization, selfreflection, and real-life problem solving (Bada \& Olusegun, 2015). An appreciation of students' knowledge frameworks is integral to designing and developing constructivism-oriented instructional materials that engender productive learning (Çimer \& Coşkun, 2018).

Constructivist learning theory positions students as active agents in the construction of knowledge from meaningful interpretations of real-life experiences (Bada \& Olusegun, 2015; Doolittle, 1999; Gross \& Gross, 2016). The consequent constructivist pedagogies have been influenced by three strands of constructivism-cognitive, radical, and social. While constructivist pedagogies share core principles with the three strands, their peripheral principles may vary. What makes a pedagogy constructivist is the assembly and rationale for the inclusion of particular principles that have been proposed by theorists over time (Doolittle, 1999; Van Bergen \& Parsell, 2019). A consensus based on the general constructivist theories and practices has resulted to the formulation of principles 
that are essential to constructivist pedagogy (Bada \& Olusegun, 2015; Doolittle, 1999), namely, (1) learning transpires in authentic and real-life settings; (2) learning involves social negotiation and mediation; (3) content and skills are made suitable to the learner; (4) content and skills are understood within the framework of the learner's prior knowledge; (5) students are assessed formatively, informing future learning experiences; (6) students are encouraged to become self-regulated, self-mediated, and self-aware; (7) teachers act as a guide and facilitator of learning; and (8) teachers provide for and encourage multiple perspectives and representations of content.

Principles of constructivist pedagogy have been adopted in numerous educational innovations, including problem-based learning, project-based learning, inquiry-based approach, and design thinking. Problem-based learning has a significant and positive effect on students' academic performance, achieving higher marks on all assessments than the control group who experienced traditional approach, according to a meta-analysis of studies, mostly from Asia, conducted from 2016 to 2020 (Funa \& Prudente, in press). Cakir (2017) examined 38 studies from 2006 to 2016 that utilized the 5E inquiry learning model and showed a positive effect on student achievement. Furthermore, Ayaz and Sekerci's (2015) analysis of studies from 2003 to 2014 suggest the effectivenes of constructivist learning approaches. These results are congruent to other metaanalyses of constructivist approaches in science education that showed increases in student academic achievement (Dochy et al., 2003; Toraman \& Demir, 2016).

The adoption of constructivist principles in the design of curriculum materials for use in emergency distance learning is an opportunity offered by the COVID-19 pandemic. The objective of the present study is to investigate secondary students' experiences with the Biology Self-Learning Modules (referred to as BSLM hereafter), whose development was informed by constructivist learning theory. Specifically, we analyzed student' perceptions of BSLM with respect to its: (1) content, which pertains to the sufficiency and accuracy of conceptual information; (2) learning-teaching activities, which refers to the various tasks and exercises such as problem solving and knowledge application; (3) assessment and evaluation, which pertains to encouraging and stimulating questions; and (4) structure, which refers to the systematic and visual representation of the modules which may be in digital or printed form. We also aimed to understand the context of students' and teachers' use of BSLM in order to draw a more holistic picture of the enactment of a pandemic pedagogy.

\section{Methodology}

\subsection{Research Design}

This study followed a survey descriptive research design (Creswell \& Creswell, 2018) to investigate using a constructivist learning framework students' perspectives on BSLM employed as an instructional material for emergency distance education during the COVID-19 pandemic. The cross-sectional survey method was implemented using Google Forms that were made accessible for two weeks in order to give participants enough time to answer. The choice to use an online data-gathering platform ensured the respondents' health safety as they can complete the survey questionnaire from home. The results from the survey were 
triangulated with online interview data from students and teachers in order to enhance credibility.

\subsection{Participants}

This study focused on Science, Technology, Engineering, and Mathematics (STEM) students in grades 11 and 12 who were taking General Biology, which is a 40-hour specialized subject in the K-12 curriculum offered to Senior High School (SHS) students. It consists of sequential courses: General Biology 1, which focuses on life processes at the cellular and molecular levels including energy transformations, and General Biology 2, which deals with the topics of heredity, variation, diversity, structure, function, and evolution of organisms.

A total of 221 SHS STEM students consented to participate in the study, with 53\% coming from grade 11, 85\% from General Biology 1, and 77\% using digitized modules. We used intensity sampling for online personal semi-structured interviews of students $(n=10)$ and their teachers $(n=11)$, both of whom used the BSLM during the conduct of the study. This sampling method allows researchers to choose participants that represent rich cases, manifesting the phenomenon of interest for in-depth analysis (Patton, 1990). The interviews sought clarifications and elaborations from students on their responses to the survey. Teachers were interviewed about the BSLM design and their interactions with students as they used BLSM, including any interventions provided.

\subsection{Instrument}

We adapted the 3-point Likert scale questionnaire developed by Çimer and Coşkun (2018), which has a Cronbach's alpha reliability coefficient of .94. This instrument was designed following a constructivist learning framework and was utilized to evaluate printed Biology textbooks. In this study, we modified the original questionnaire to evaluate a similar curriculum resource, the BSLM, both in printed and digitized forms. The modified instrument consists of four parts: (1) content, 26 items; (2) learning-teaching activities, 30 items; (3) assessment and evaluation activities, 15 items; and (4) structure (originally "physical design"), 14 items. The items in the first three parts of the instrument were retained with minor changes in terminology; "textbook" was changed to "modules". The items in the last part were rephrased to appropriately refer to the two available BSLM formats. For instance, we replaced the word "letterpress" with "text" since the former is applicable only to the printed version. Similarly, references to size, weight, durability, and paper quality were altered to refer to visual features instead.

The adapted questionnaire retained the 3-point scale for the same reason stated by Çimer and Coşkun (2018); it offers a clearer interpretation of the findings. According to Lehmann and Hulbert (1972), a 3-point Likert scale is good enough for a study whose main interest is to obtain averages across a group of people and not generate a behavior profile of individual persons. The adapted questionnaire was evaluated and approved by eleven education experts composed of master teachers and experienced Biology teachers.

\subsection{Data Collection}

We sought permission from various DepEd division offices across the country. Only four division offices officially endorsed and disseminated the link to the 
online survey through their respective science education program supervisors. Observing ethical conduct of research, only students whose parent or guardian signed the printed consent forms coursed through their teachers were included in the study. The link to the online survey in Google Forms was sent to studentrespondents. Only students who have used either General Biology 1 or General Biology 2 module for at least two months were included in the data gathering and analysis. Interview data were collected after the preliminary analysis of survey data. This allowed the crafting of specific and targeted questions to be used in the online interview sessions.

\subsection{Data Analysis}

We used a 3-point Likert scale questionnaire (1-Disagree, 2-Undecided, and 3Agree) to obtain students' evaluation of the modules according to a constructivist learning theory. The ordinal data obtained from the questionnaire were subjected to descriptive statistical analysis and presented accordingly: students' views on the content (A1-A26), learning-teaching activities (B1-B30), assessment and evaluation activities (C1-C15), and structure (D1-D14).

\section{Findings}

In this section, we present the findings of the survey with respect to the four aspects of the BLSM evaluated by students. We highlight the items with the high and low percentage agreement in order to identify features of the curriculum that could be retained and improved upon, respectively, in future iterations. Also, we provide complementary interview data in order to clarify particular results and provide a fuller understanding of contextual influences on students' interaction with BSLM.

\subsection{Students' Views on the Content of Biology Modules}

The majority of the students perceived the content of the modules used during the COVID-19 pandemic as fostering understanding of biology concepts, as shown in Table 1. Many agreed that the visuals used (e.g., diagrams, pictures, tables, graphs, figures, etc.) coordinated well with the topics and helped them interpret information (A24, A2, A19). They also found the topic presentation to be welldesigned-being grade-appropriate and logically arranged (A22). The links between topics (A4) were also noted by many, with almost two-thirds of students agreeing that the module content exhibits interdisciplinarity (Jacobs, 1989) in its appreciable association with other subjects like Physics and Chemistry (A1). In addition, almost half of them agreed with the real-world applicability of the module content (A6, A26, A12). Timeliness, suitability, and integrability of discipline-based knowledge are given importance in constructivist approaches. These features allow learners to cross boundaries between disciplines and effectively apply their learning to solve authentic and real-life problems (Bada \& Olusegun, 2015; Doolittle, 1999; Gross \& Gross, 2016). 
Table 1: Students' views on the content of Biology modules

\begin{tabular}{|c|c|c|c|c|}
\hline & Items* & $\begin{array}{c}\text { Disagree } \\
(\%)\end{array}$ & $\begin{array}{l}\text { Undecided } \\
(\%)\end{array}$ & $\begin{array}{c}\text { Agree } \\
(\%)\end{array}$ \\
\hline A24 & $\begin{array}{l}\text { Pictures, graphs, figures, and tables in the } \\
\text { module are appropriate to the topics. }\end{array}$ & 1 & 12 & 87 \\
\hline A2 & $\begin{array}{l}\text { Tables, graphs, or figures provided in the } \\
\text { module help us acquire and interpret } \\
\text { information. }\end{array}$ & 4 & 13 & 83 \\
\hline A22 & $\begin{array}{l}\text { The topics in the module are appropriate to our } \\
\text { learning level. }\end{array}$ & 1 & 16 & 83 \\
\hline A4 & The topics are connected to each other. & 3 & 15 & 82 \\
\hline A19 & $\begin{array}{l}\text { Descriptions are provided under pictures, } \\
\text { graphics, figures, and tables. }\end{array}$ & 5 & 18 & 77 \\
\hline A25 & Topics are arranged in a logical sequence. & 4 & 26 & 71 \\
\hline A21 & $\begin{array}{l}\text { At the end of a topic, there are additional } \\
\text { resources that allow us to obtain more detailed } \\
\text { information. }\end{array}$ & 7 & 24 & 69 \\
\hline A1 & $\begin{array}{l}\text { When necessary, the topics relate to those in } \\
\text { other subjects (Physics, Chemistry, etc.). }\end{array}$ & 5 & 28 & 67 \\
\hline A5 & $\begin{array}{l}\text { The topics in the module are taught using brief } \\
\text { and concise information. }\end{array}$ & 9 & 26 & 65 \\
\hline A6 & $\begin{array}{l}\text { When presenting the topics, current events are } \\
\text { used as examples. }\end{array}$ & 9 & 26 & 65 \\
\hline A10 & $\begin{array}{l}\text { Essential knowledge related to the topics in the } \\
\text { module is distinctly emphasized. }\end{array}$ & 5 & 30 & 65 \\
\hline A18 & Summaries are provided at the end of sections. & 11 & 24 & 65 \\
\hline A3 & Topics are discussed in a detailed manner. & 10 & 27 & 63 \\
\hline A8 & $\begin{array}{l}\text { The module is sufficient for us to learn basic } \\
\text { biological concepts. }\end{array}$ & 11 & 26 & 63 \\
\hline A26 & $\begin{array}{l}\text { At the end of each topic, reading texts are } \\
\text { provided in the module that make it easy to } \\
\text { establish a connection with current events. }\end{array}$ & 7 & 30 & 63 \\
\hline A15 & $\begin{array}{l}\text { The historical development of biology is also } \\
\text { discussed in the module. }\end{array}$ & 10 & 29 & 62 \\
\hline A11 & $\begin{array}{l}\text { I must use other resources because the topics in } \\
\text { the module are superficially presented. }\end{array}$ & 9 & 30 & 61 \\
\hline A16 & The module includes numerous definitions. & 15 & 24 & 61 \\
\hline A23 & $\begin{array}{l}\text { The information provided in the module is up } \\
\text { to date. }\end{array}$ & 5 & 36 & 60 \\
\hline A12 & $\begin{array}{l}\text { I can use the knowledge I have acquired from } \\
\text { the module to solve biology-related problems } \\
\text { that I encounter in my daily life. }\end{array}$ & 8 & 33 & 59 \\
\hline A9 & $\begin{array}{l}\text { Detailed definitions of biological concepts or } \\
\text { terms are provided in the module. }\end{array}$ & 10 & 33 & 57 \\
\hline A14 & $\begin{array}{l}\text { The topics are enriched with examples from } \\
\text { daily life. }\end{array}$ & 10 & 39 & 51 \\
\hline A17 & $\begin{array}{l}\text { The number of examples for each topic is } \\
\text { adequate. }\end{array}$ & 13 & 39 & 48 \\
\hline A20 & $\begin{array}{l}\text { The module includes excessive and unnecessary } \\
\text { knowledge that I will not use in my daily life. }\end{array}$ & 46 & 37 & 17 \\
\hline A7 & $\begin{array}{l}\text { The topics in the module are not presented } \\
\text { according to the class level. }\end{array}$ & 41 & 46 & 13 \\
\hline A13 & $\begin{array}{l}\text { I often encounter inaccurate information in the } \\
\text { module. }\end{array}$ & 35 & 47 & 18 \\
\hline
\end{tabular}

Note: *Adapted from Çimer and Coşkun (2018). 
In addition, a large percentage of students agreed that the module content is brief, concise (A5), adequate (A21, A8), and presented in a detailed (A3) and logically arranged manner (A25). Section summaries and links to additional resources helped students deepen their understanding of topics. However, most students were undecided about information accuracy (A13 $=47 \%$ ), even as some assessed the content to contain no misinformation at all (37\%). Perhaps the former felt they could not possibly make a competent judgment on this aspect. Although most students found the content sufficient, still others viewed its presentation as superficially because they would still need to use supplemental resources. Based on interviews with teacher, the information could appear superficial because they only included the MELCs. As the name suggests, MELCs are trimmed down content representing the most basic topics that the DepEd determined students needed to know during this time of pandemic learning.

Constructivist approaches do not require outrightly providing detailed expositions of concepts to be learned. Instead, they guide students to integrate prior and newly presented knowledge to construct meanings through searching, analyzing, and interpreting (Çimer \& Coskun, 2018). Thus, students are expected to use various resources while teachers guide them in the discovery, construction, and application of knowledge. This was done in BSLM through scaffolded lessons with links to other resources provided to supplement learning. Specifically, BSLM developers, as explained by one teacher interviewee, followed the 5E inquiry teaching model (Bybee et al., 2006). It features an instructional sequence (Engage, Explore, Explain, Evaluate, and Elaborate) that is used to practically implement an implicit constructivist teaching and learning approach (Boddy et al, 2003; Bybee, 1997; Bybee \& Powell, 1993). Scaffolding features employed in BSLM align with a constructivist approach and guide the development of students' conceptual understanding.

\subsection{Students' Views on the Learning-Teaching Activities of Biology Modules}

A majority of the students viewed the BSLM as helping to stimulate their thinking (B2, B21), enable self-expression (B18), encourage the use of other resources (B25), and construct their own understanding (B5), as shown in Table 2. These results correspond to what emerged in the survey as the most salient learning activity features for students. Constructivism enjoins teachers: to encourage students to be independent and accountable for their own learning; provide them multiple perspectives and representations; and allow them to express learning in various forms (Bada \& Olusegun, 2015; Doolittle, 1999).

Table 2: Students' views on the learning-teaching activities of Biology modules

\begin{tabular}{llrrr}
\hline \hline & \multicolumn{1}{c}{ Items $^{*}$} & $\begin{array}{c}\text { Disagree } \\
(\mathbf{\%})\end{array}$ & $\begin{array}{c}\text { Undecided } \\
(\mathbf{\%})\end{array}$ & $\begin{array}{c}\text { Agree } \\
\mathbf{( \% )}\end{array}$ \\
\hline B2 & $\begin{array}{l}\text { Activities and questions in the module stimulate } \\
\text { us to think. }\end{array}$ & 1 & 10 & 88 \\
B18 & $\begin{array}{l}\text { The activities in the module enable us to express } \\
\text { our ideas and opinions related to the lesson. } \\
\text { Questions and activities in the module } \\
\text { encourage us to think about the topics and } \\
\text { interpret them. }\end{array}$ & 3 & 15 & 82
\end{tabular}


B25 The activities in the module encourage us to

B5 Activities in the module encourage us to take

B20 The module serves as a guide that shows us

how to use the knowledge, skills, and experiences that we have acquired from the lessons.

B30 Application instructions for the activities are provided.

B11 The module includes preparatory questions and activities that attempt to gauge our existing knowledge before the beginning of each unit or topic.

B16 The activities in the module reinforce our understanding and learning of the topics.

B19 The module includes activities that allow us to look at daily life problems from different perspectives while trying to solve them.

B26 The module contains various activities that enable us to present our knowledge and skills in different ways.

B4 The module includes activities that allow us to participate in the lesson actively.

B15 The activities in the module allow us to learn other students' opinions and ideas on the topics.

B6 Activities in the module offer us different learning environments.

B8 Activities in the module are suitable for our ability level.

B1 The module offers problems to solve that are related to daily life.

B24 The teacher must describe the activities in the module.

B13 The provided experiments facilitate our understanding of the topics.

B22 The activities in the module allow us to discuss the subjects in class.

B29 The topics in the module are arranged in an increasing order of difficulty.

B14 The module contains activities or questions requiring us to design our own experiments.

B27 The methods to conduct experiments are described in detail in the module.

B28 The module includes such activities as structured grids or componential analysis tables.

B12 The activities in the module enable us to acquire knowledge without the teacher's help.

B17 The module includes such activities as field visits, observation, and investigations.

B23 The activities in the module are focused on solving daily life problems or situations.

B3 Teachers' role in the activities is minimal.

B10 Activities in the module require us to work in groups.

\begin{tabular}{|c|c|}
\hline 2 & 20 \\
\hline 3 & 20 \\
\hline 1 & 22 \\
\hline 6 & 17 \\
\hline 3 & 20 \\
\hline 5 & 25 \\
\hline 9 & 21 \\
\hline 8 & 24 \\
\hline 4 & 29 \\
\hline 8 & 27 \\
\hline 13 & 23 \\
\hline 6 & 40 \\
\hline 12 & 38 \\
\hline 11 & 39 \\
\hline 9 & 45 \\
\hline 10 & 45 \\
\hline 13 & 42 \\
\hline 21 & 36 \\
\hline 31 & 33 \\
\hline 15 & 48 \\
\hline 19 & 49 \\
\hline 26 & 45 \\
\hline
\end{tabular}



given in the module.

Note: *Adapted from Çimer and Coşkun (2018).

Based on the interviews, the teachers, using the $5 \mathrm{E}$ model, presented stimulating problems at the beginning of each module to encourage students to recall past lessons in order to activate prior knowledge. For example, some of the recall questions in the Engage phase for the lesson Prokaryotic vs Eukaryotic Cells include: "Have you experienced having an infected wound? How about a ringworm? What do you think causes these infections/skin diseases? What is usually prescribed when you have an infected wound? A ringworm? Are these two caused by the same organism?" To enable expression of learning, teachers provided activities in the Extend phase that solicited students' insights by completing prompts such as "I have learned that..." and "I wish to ask my teacher about..." Furthermore, to enrich learning through varied representations, students were engaged in different performance activities, such as singing a rap song related to the cell theory, making a 3-D cell model, investigating enzyme activities using chicken liver, and watching videos through weblinks provided in the modules.

Remarkably, a little more than one-third of students unequivocally disagreed that they can easily carry out laboratory activities (B7) whereas almost half of them were ambivalent about this statement. In addition, half of the students agreed that the time allocated for conducting activities is not enough (B9). These results point to the changes in mode of learning due to the pandemic. The difficulty felt by students in performing activities may be attributed to the unavailability of the needed materials and equipment at home (Tria, 2020; Williamson et al., 2020). A challenge to module designers is to create activities that use materials that are easily sourced. However, according to teachers interviewed, they in fact designed laboratory activities that could be performed using materials found at home (Tria, 2020; Williamson et al., 2020). They instructed students to ask their parents' assistance to ensure safety when performing the experiments. Anticipating that students would have questions and experience difficulties, teachers opened communication channels through online group chats, text messaging, or phone calls. They even gave deadline extensions and provided work plans with agreed timelines to relieve some pressure due to time constraints.

Students were divided on the question of module activities requiring collaboration with others (B10). According to constructivist approaches, learning involves social negotiation and mediation (Bada \& Olusegun, 2015; Doolittle, 1999). The social interaction is strongly related to students' learning enjoyment and may affect their attitude towards education (Marcial et al., 2015). During the interviews, teachers said that they avoided group activities as much as possible during the pandemic to prevent students from COVID-19 exposure and infection. They only allowed group tasks for students who can perform online group activities. However, in order for online group learning to be successful, there is a need to minimize the cost of, and improve the quality of access to, the Internet (Marcial et al., 2015; Tria, 2020; Williamson et al., 2020). This technological 
infrastructure challenge is a systemic problem in a third world country like the Philippines (Albert et al., 2016; Akamai, 2017) and is more acute in rural areas than in urban ones. Given this situation, it seems that group work would have to be paused until the pandemic ends. The problems students encountered in performing tasks online, such as the unavailability of materials and constraints on time and conducting group work, to some extent parallel the challenges experienced by Pakistani students (Adnan \& Anwar, 2020). The difficulties perceived by students suggest the need to aim for a socially just digital inclusiveness in designing modules (Williamson et al., 2020).

\subsection{Students' Views on the Assessment and Evaluation of Biology Modules}

Most of the students had a positive appraisal of the assessment and evaluation activities of BSLM, as shown in Table 3. They regarded the module questions as letting them identify the level of their current knowledge $(\mathrm{C} 2)$, prompting thinking $(\mathrm{C} 4, \mathrm{C} 1)$, and evaluating their own learning $(\mathrm{C} 10, \mathrm{C} 11)$. These results reveal that the most noticeable constructivist features for students are eliciting prior knowledge, inducing thinking, and evaluating one's own learning. Each module was designed with pre- and post-tests, with an answer key provided at the end of the module to allow students to evaluate their own learning. In addition, students were also provided reflection questions - what they have learned and what they still wanted to learn - to assess their current understanding of the lesson.

Table 3: Students' views on the assessment and evaluation of Biology modules

\begin{tabular}{|c|c|c|c|c|}
\hline & Items* & $\begin{array}{c}\text { Disagree } \\
(\%)\end{array}$ & $\begin{array}{c}\text { Undecided } \\
(\%)\end{array}$ & $\begin{array}{c}\text { Agree } \\
(\%)\end{array}$ \\
\hline $\mathrm{C} 4$ & $\begin{array}{l}\text { The module contains questions that prompt } \\
\text { us to rethink and interpret the relevant } \\
\text { information. }\end{array}$ & 2 & 14 & 84 \\
\hline C10 & $\begin{array}{l}\text { The module contains activities enabling us to } \\
\text { assess our own learning. }\end{array}$ & 1 & 15 & 84 \\
\hline $\mathrm{C} 2$ & $\begin{array}{l}\text { The module contains questions or activities } \\
\text { that aim to clarify the level of our existing } \\
\text { knowledge at the beginning of a new topic. }\end{array}$ & 3 & 14 & 83 \\
\hline C11 & $\begin{array}{l}\text { The module contains different types of } \\
\text { questions seeking to evaluate if we have } \\
\text { understood the subjects. }\end{array}$ & 2 & 17 & 81 \\
\hline $\mathrm{C} 1$ & $\begin{array}{l}\text { Preparatory activities related to the topics } \\
\text { stimulate us to think and make inquiries. }\end{array}$ & 2 & 18 & 80 \\
\hline C5 & $\begin{array}{l}\text { The module contains evaluative questions at } \\
\text { the end of each topic or section. }\end{array}$ & 3 & 19 & 78 \\
\hline C7 & $\begin{array}{l}\text { The module contains questions that encourage } \\
\text { us to express our own ideas and experiences. }\end{array}$ & 3 & 20 & 77 \\
\hline C14 & $\begin{array}{l}\text { The module contains questions requiring us to } \\
\text { interpret the tables, graph, or pictures } \\
\text { included within a topic. }\end{array}$ & 6 & 25 & 68 \\
\hline $\mathrm{C} 12$ & $\begin{array}{l}\text { The module contains performance tasks that } \\
\text { we can mentioned in our portfolios. }\end{array}$ & 5 & 30 & 65 \\
\hline C13 & $\begin{array}{l}\text { The module contains various questions, tasks, } \\
\text { or assignments that encourage us to conduct } \\
\text { research and investigation. }\end{array}$ & 8 & 29 & 63 \\
\hline
\end{tabular}


C15 We generally face difficulties in answering the

questions in the module.

C9 Preparatory questions or activities at the

beginning of the topics attract our attention.

C8 Performance tasks and assignments attract

our attention.

C6 The questions provided at the end of each

topic or section are not adequate to evaluate if we have understood the topic.

C3 Questions in the module are not sufficient to reinforce our learning and understanding of the topics.

Note: *Adapted from Çimer and Coşkun (2018).

More than half of the students reported that they faced difficulties in answering modules questions (C15). In an interview, a student who used the digitized version of BSLM shared that the slow internet connection, limited mobility due to community restrictions during the pandemic, and lack of tools, such as mobile phones, computers, and laboratory instruments, led to his difficulties in completing learning tasks, including accessing weblinks to supplemental materials. These impediments to accessing knowledge resources in the community and the Internet constrained students' engagement with the learning materials (Pear \& Crone-Todd, 2002; Tria, 2020; Williamson et al., 2020). In response, teachers sought ways to support and provide assistance to students experiencing difficulties. For instance, they enlisted the help of persons (e.g., a student's classmates or an official in the community) to relay necessary information. In some cases, teachers visited students to personally attend to their educational needs following COVID-19 protocols.

\subsection{Students' Views on the Structure (Printed and Digitized) of Biology Modules}

Students' positive appraisal of the structure of BSLM in both printed and digitized format (Table 4) referred to its clear, intelligible, and comprehensible use of language (D8, D5), use of visuals that appropriately facilitate better understanding (D13, D3, D7), and proper technical aspects of writing (D9).

Table 4: Students' views on the structure of Biology modules

\begin{tabular}{|c|c|c|c|c|c|c|c|}
\hline & \multirow[t]{2}{*}{ Items } & \multicolumn{3}{|c|}{$\begin{array}{l}\text { Printed } \\
(n=67)\end{array}$} & \multicolumn{3}{|c|}{$\begin{array}{c}\text { Digitized } \\
(n=154)\end{array}$} \\
\hline & & $\begin{array}{c}1 \\
(\%)\end{array}$ & $\begin{array}{c}2 \\
(\%)\end{array}$ & $\begin{array}{c}3 \\
(\%)\end{array}$ & $\begin{array}{c}1 \\
(\%)\end{array}$ & $\begin{array}{c}2 \\
(\%)\end{array}$ & $\begin{array}{c}3 \\
\\
(\%)\end{array}$ \\
\hline D8 & $\begin{array}{l}\text { The module uses clear and intelligible } \\
\text { language }\end{array}$ & 6 & 19 & 75 & 3 & 20 & 77 \\
\hline D5 & $\begin{array}{l}\text { The module uses language that has a } \\
\text { natural flow and is comprehensible. }\end{array}$ & 3 & 18 & 79 & 3 & 21 & 76 \\
\hline D13 & $\begin{array}{l}\text { Pictures, graphs, figures, and tables in the } \\
\text { module are appropriate to our learning } \\
\text { level. }\end{array}$ & 2 & 27 & 72 & 4 & 21 & 75 \\
\hline D3 & $\begin{array}{l}\text { Visuals and graphic organizers are } \\
\text { available to facilitate better understanding } \\
\text { of the lesson. }\end{array}$ & 6 & 22 & 72 & 5 & 22 & 73 \\
\hline
\end{tabular}




\begin{tabular}{|c|c|c|c|c|c|c|c|}
\hline D7 & $\begin{array}{l}\text { Visual materials such as pictures, graphs, } \\
\text { figures, and tables are placed appropriately } \\
\text { in the module. }\end{array}$ & 6 & 22 & 72 & 5 & 22 & 73 \\
\hline D9 & $\begin{array}{l}\text { Punctuation and spelling rules are strictly } \\
\text { followed in the text. }\end{array}$ & 2 & 21 & 78 & 5 & 26 & 70 \\
\hline D2 & $\begin{array}{l}\text { The lessons are arranged from simple to } \\
\text { complex. }\end{array}$ & 8 & 28 & 64 & 8 & 29 & 62 \\
\hline D6 & $\begin{array}{l}\text { The module is visually engaging and } \\
\text { interesting. }\end{array}$ & 6 & 27 & 67 & 8 & 35 & 57 \\
\hline D11 & $\begin{array}{l}\text { The colors used of visual materials such as } \\
\text { photos, pictures, and tables in the module } \\
\text { are attractive and interesting. }\end{array}$ & 9 & 33 & 58 & 8 & 36 & 57 \\
\hline D10 & $\begin{array}{l}\text { There are too many typographical errors in } \\
\text { the module. }\end{array}$ & 46 & 43 & 10 & 54 & 32 & 14 \\
\hline D4 & $\begin{array}{l}\text { Remarkable, motivating, and vibrant colors } \\
\text { are used sufficiently in the module. }\end{array}$ & 19 & 31 & 49 & 9 & 42 & 49 \\
\hline D1 & $\begin{array}{l}\text { The texts in the module are clear and easy } \\
\text { to understand. }\end{array}$ & 19 & 36 & 45 & 12 & 40 & 49 \\
\hline D14 & $\begin{array}{l}\text { Long sentences are used for presenting } \\
\text { information in the module. }\end{array}$ & 9 & 31 & 60 & 13 & 42 & 44 \\
\hline D12 & $\begin{array}{l}\text { There are too many unfamiliar words in the } \\
\text { module that we cannot understand. }\end{array}$ & 24 & 37 & 39 & 35 & 43 & 21 \\
\hline
\end{tabular}

Notes: 1 = Disagree, $2=$ Undecided, and $3=$ Agree. ${ }^{*}$ Adapted from Çimer and Coşkun (2018).

Many of the students reported that there are too many unfamiliar words (D12), more from students who used printed modules (39\%) compared to those who used digitized modules $(21 \%)$. Students who opted for print modules generally belong to the low socio-economic group who have problems in internet connectivity and/or lack electronic gadgets (Tria, 2020). As such, they have no access to supporting online resources when faced with learning difficulties, such as when confronted with unfamiliar words. In designing BSLM, teachers provisioned a glossary section that students could refer to. Some of them also offered helplines through various communication channels. Teachers recognized that it is important that the BSLM are complemented by external modes of support.

\section{Conclusion}

This study set out to understand students' experiences with the Biology selflearning modules, which was rapidly developed and deployed as part of emergency distance education. We investigated students' interactions with the new curriculum material using an online survey questionnaire informed by constructivist learning theory and conducted online interviews with students and teachers to better understand the contextual influences on their participation in science learning and teaching.

Students' evaluation of the BSLM is largely positive. In general, they considered the content and activities as timely, suitable, sufficient, applicable to real-life situations, and relatable to other disciplines. The activities, assessment, and evaluation in the modules encourage independence and responsibility towards one own learning, provide various opportunities to express learning, and guide to develop new understandings. The use of scaffolding and visual elements, like 
diagrams and pictures, helped them to better understand concepts. Students viewed the structure of the module positively, noticing its clarity, comprehensibility, and correctness of language, grammar, and spelling. These BSLM design features that were salient to a majority of the students suggest that constructivist learning could somehow be achieved even in an emergency distance education context.

However, students' engagement with the BSLM was not without any challenges. There were students who perceived the presentation of content as superficial and some activities unimplementable (e.g., laboratory activities) at home because of the unavailability of necessary materials. Some recognized that group tasks may be difficult to accomplish when they are homebound and lack access to technologies for remote collaboration. Still others found some module questions difficult to answer because of, again, impediments in accessing knowledge resources in the community and the Internet. Digital inequalities remained acute and contributed to students' differential participation in learning activities.

Teachers found ways to try to mitigate the consequences of digital inequalities. They offered alternative activities, requested parents' assistance, adjusted deadlines, suggested doable workplans, and opened various channels of communication and support. Teachers' accommodations and extensions of help became necessary elements of a pandemic pedagogy.

Learning about the students' experiences with new curriculum materials is productive in informing future design efforts. The results of this study may be used by teachers and other instructional designers to improve materials for emergency distance learning. It does not only provide insight into design features that could support constructivist learning but also suggest complementary support structures needed to address digital inequalities. With the COVID-19 pandemic suspending conventional education, putting at greater risk the intellectual and social development of children and adolescents, it is important to appraise proposed remedies in order to fine tune our emergency response.

\section{References}

Adnan, M., \& Anwar, K. (2020). Online learning amid the COVID-19 pandemic: Students' perspectives. Journal of Pedagogical Sociology and Psychology, 2(1), 45-51. https://doi.org/10.33902/JPSP.\%202020261309

Albert, J. R. G., Serafica, R. B., \& Lumbera, B. T. (2016). Examining trends in ICT statistics: How does the Philippines fare in ICT? (No. 2016-16). PIDS Discussion Paper Series.

Akamai (2017). Akamai's state of the internet. Akamai, 10(1). https://www.akamai.com/us/en/multimedia/documents/state-of-theinternet/q1-2017-state-of-the-internet-connectivity-report.pdf

Ayaz, M. F., \& Sekerci, H. (2015). The effects of the constructivist learning approach on student's academic achievement: A meta-analysis study. Turkish Online Journal of Educational Technology-TOJET, 14(4), 143-156.

Bada, S. O., \& Olusegun, S. (2015). Constructivism learning theory: A paradigm for teaching and learning. Journal of Research \& Method in Education, 5(6), 66-70.

Boddy, N., Watson, K., \& Aubusson, P. (2003). A trial of the five Es: A referent model for constructivist teaching and learning. Research in Science Education, 33(1), 27-42. https://doi.org/10.1023/A:1023606425452 
Bybee, R. W. (1997). Achieving scientific literacy: From purposes to practices. Portsmouth, UK: Heinemann.

Bybee, R. W., \& Powell, J. C. (1993). Investigating diversity and limits, middle school science and technology. Dubuque, IA: Kendall Publishing.

Bybee, R. W., Taylor, J. A., Gardner, A., Van Scotter, P., Powell, J. C., Westbrook, A., \& Landes, N. (2006). The BSCS 5E instructional model: Origins and effectiveness. Biological Sciences Curriculum Study.

Caggiano, G., Castelnuovo, E., \& Kima, R. (2020). The global effects of COVID-19-induced uncertainty. SSRN Electronic Journal. https://doi.org/10.2139/ssrn.3598710

Cakir, N. K. (2017). Effect of 5E learning model on academic achievement, attitude and science process skills: Meta-analysis study. Journal of Education and Training Studies, 5(11), 157-170. https://doi.org/10.11114/jets.v5i11.2649

Çimer, A. (2012). What makes biology learning difficult and effective: Students' views. Educational Research and Reviews, 7(3), 61-71. https://doi.org/10.5897/ERR11.205

Çimer, A., \& Coskun, S. (2018). Students' opinions about their ninth grade biology textbook: From the perspective of constructivist learning approach. Journal of Education and Learning, 7(4), 201-214. https://doi.org/10.5539/jel.v7n4p201

Creswell, J. W. \& Creswell, J. D. (2018). Research design: qualitative, quantitative, and mixed methods approaches ( $5^{\text {th }}$ ed.). Los Angeles: SAGE publications. https://doi.org/10.1002/nha3.20258

Department of Education. (2020a). The basic education learning continuity plan. (DepEd Order No. 12, s. 2020).

Department of Education. (2020b). Policy guidelines for the provision of learning resources in the implementation of the basic education learning continuity plan (DepEd Order No. 018, s. 2020). Department of Education.

Department of Education. (2019a). Policy guidelines on the $k$ to 12 basic education program (DepEd Order No. 021, s. 2019). Department of Education.

Department of Education. (2019b). Alternative delivery mode learning resource standards (ADMLR STANDARDS) [version 12]. Department of Education.

Dochy, F., Segers, M., Van den Bossche, P., \& Gijbels, D. (2003). Effects of problem-based learning: A meta-analysis. Learning and Instruction, 13(5), 533-568. https://doi.org/10.3102\%2F00346543075001027

Doolittle, P. E. (1999). Constructivism and online education. Virginia Polytechnic Institute and State University.

Funa, A. \& Prudente, M. (in press). Effectiveness of problem-based learning on secondary students' achievement in science: A meta-analysis. International Journal of Instruction.

Gross, K., \& Gross, S. (2016). Transformation: Constructivism, design thinking, and elementary STEAM. Art Education, 69(6), 36-34. https://doi.org/10.1080/00043125.2016.1224869

Gutierrez, A. F. (2014). Development and effectiveness of an educational card game as supplementary material in understanding selected topics in biology. CBE life sciences education, 13(1), 76-82. https://doi.org/10.1187/cbe.13-05-0093

Jacobs, H. H. (1989). Interdisciplinary curriculum: Design and implementation. Association for Supervision, and Curriculum Development, 1250 N. Pitt Street, Alexandria, VA 22314.

Lehmann, D., \& Hulbert, J. (1972). Are three-point scales always good enough? Journal of Marketing Research, 9(4), 444-446. https:// doi.org/10.2307/3149313

Marcial, D. E., Caballero, R. D. B., Rendal, J. B., \& Patrimonio, G. A. (2015). “I am offline”: Measuring barriers to open online learning in the Philippines. Information 
$\begin{array}{llll}\text { Technologies and Learning } & \text { Tools, }\end{array}$ https://doi.org/10.33407/itlt.v45i1.1170

Patton, M. (1990). Qualitative evaluation and research methods (pp.169-186). Beverly Hills, CA: Sage. https://doi.org/10.1002/nur.4770140111

Pear, J. J., \& Crone-Todd, D. E. (2002). A social constructivist approach to computermediated instruction. Computers $\mathcal{E}$ Education. 38(1-3), 221-231. https:// doi.org/10.1023/A:1024558414766

Sañosa, M. (2013). Implementation of $K$ to 12 curriculum program among grade 7 science teachers in Eastern Visayas. Journal of Society and Technology, 3, 37-44

Talidong, K. J. B., \& Toquero, C. M. D. (2020). Philippine teachers' practices to deal with anxiety amid COVID-19. Journal of Loss and Trauma, 25(6-7), 573-579. https:// doi.org/10.1080/15325024.2020.1759225

Toraman, C., \& Demir, E. (2016). The effect of constructivism on attitudes towards lessons: A meta-analysis study. Eurasian Journal of Educational Research, 62, 115-142. https://doi.org/10.14689/ejer.2016.62.8

Tria, J. Z. (2020). The COVID-19 pandemic through the lens of education in the Philippines: The new normal. International Journal of Pedagogical Development and Lifelong Learning, 1(1), 2-4.

Van Bergen, P., \& Parsell, M. (2019). Comparing radical, social and psychological constructivism in Australian higher education: A psycho-philosophical perspective. The Australian Educational Researcher, 46(1), 41-58. https://doi.org/10.1007/s13384-018-0285-8

Williamson, B., Eynon, R., \& Potter, J. (2020). Pandemic politics, pedagogies and practices: Digital technologies and distance education during the coronavirus emergency. Learning, Media and Technology, 45(2), 107-114. https://10.10bslm80/17439884.2020.1761641 